\title{
Kombinasi Proses Presipitasi dan Adsorpsi untuk Menangani Limbah Bahan Berbahaya Beracun (B3) Hasil Kegiatan Analisis di Laboratorium Analisis Polinela
}

\section{Combination of Precipitation and Adsorption Processes to Handle Toxic Hazardous Waste (B3) Results of Analysis Activities at the Polinela Analysis Laboratory}

\author{
Ismadi Raharjo, Didik Kuswadi \\ Dosen Program Studi Teknik Sumberdaya Lahan dan Lingkungan, \\ Jurusan Teknologi Pertanian, Politeknik Negeri Lampung \\ Jl. Soekarno-Hatta, Rajabasa, Bandar Lampung 35144 Tel. (0721)703995
}

\begin{abstract}
The objectives of this research to determine the combination of the process of precipitation and adsorption in reducing the content of pollutant metals in the hazardous waste category B3 (hazardous toxic substances) produced at the Polinela Analysis Laboratory. The study was conducted in May to November 2019. The results obtained from 3 (three) times of sampling in May 2019 obtained a description of the characteristics of heavy metal content in wastewater in the form of Aluminum ( $\mathrm{Al}$ ) an average of $1.59 \mathrm{ppm}$, iron content ( $\mathrm{Fe}$ ) an average of $9.73 \mathrm{ppm}$ and Cadmium $(C d)$ an average of $0.022 \mathrm{ppm}$. From these results it can be seen that the wastewater containing $\mathrm{Al}$ and Fe has passed the threshold quality standard of waste water that is allowed to be discharged into water resource (PP No.82 of 2001), while the Cd content is still below the threshold. Furthermore, through the precipitation process with $\mathrm{Ca}(\mathrm{OH})_{2} \mathrm{O} .8 \mathrm{M}$ and adsorption using activated charcoal with contact time of 3 (three) hours the content of pollutants in wastewater can be reduced to 0.92 ppm for Al metals and 0.1 ppm for metals $\mathrm{Fe}$, so that it is below the standard quality of waste water that is allowed to drain in water.
\end{abstract}

Keywords: adsorption, precipitation, quality standard

Naskah ini diterima pada tanggal 2 Juni 2020, direvisi pada tanggal 16 Juni 2020 dan disetujui untuk diterbitkan pada tanggal 15 Agustus 2020

\section{PENDAHULUAN}

\section{Latar belakang}

Laboratorium Analisis Politeknik Negeri Lampung merupakan salah satu laboratorium yang berfungsi ganda. Selain menjadi laboratorium yang menjalankan fungsi pelayanan akademik sebagai laboratorium umum, juga menjalankan fungsi untuk jasa pelayanan uji atau analisis sampel bagi para pihak yang membutuhkan.

Kegiatan tersebut membutuhkan bahan-bahan kimia dan pendukung sesuai dengan prosedur analisa yang digunakan. Jenis bahan kimia yang umum dipakai antara lain bahan yang berupa asam kuat seperti Asam Klorida $(\mathrm{HCl})$, Asam Nitrat $\left(\mathrm{HNO}_{3}\right)$, dan Asam Sulat $\left(\mathrm{H}_{2} \mathrm{SO}_{4}\right)$ : 
bahan yang berupa basa kuat seperti Natrium Hidroksida ( $\mathrm{Na} \mathrm{OH})$ dan Kalium Hidroksida $(\mathrm{KOH})$; serta kelompok kimia anorganik berupa Magnesium $\left(\mathrm{MgCl}_{2}\right)$, Kalium Klorida $(\mathrm{KCl})$, Merkuri Sulfat $\left(\mathrm{Hg} \mathrm{SO}_{4}\right)$, Kalium Khromat $\left(\mathrm{KCr} \mathrm{O}_{4}\right)$, Kalium Bikhromat $\left(\mathrm{K}_{2} \mathrm{CrO}_{7}\right)$, Ferro Amonium Sulfat $\left(\mathrm{Fe}\left(\mathrm{NH}_{4} \mathrm{SO}_{4}\right)\right.$, dan bahan-bahan yang lain

Konsekuensi dari aktifitas uji di laboratorium tersebut, maka selalu menghasilkan limbah cair yang mengandung zat berbahaya dan sering disebut sebagai limbah bahan berbahaya dan beracun (B3) seperti logam berat beracun seperti besi $(\mathrm{Fe})$, Cadmium $(\mathrm{Cd})$, Tembaga $(\mathrm{Cu})$, dan Timbal $(\mathrm{Pb})$.

Apabila limbah cair tersebut tanpa diolah dan langsung dibuang ke alam, maka akan menimbulkan masalah lingkungan terutama tercemarnya air tanah yang akan merugikan manusia dan hewan di sekitarnya. Masalah ekosistem yang berupa tercemarnya air tanah akan memerlukan waktu yang lama untuk memulihkanya. Untuk menjadi Laboratorium yang terakreditasi (ISO 17025), dimana mensyaratkan Laboratorium harus menangani Limbah B3 secara baik, Laboratorium Analisis Polinela harus mempersiapkan diri untuk mengolah limbah hasil samping proses kimiawi tersebut secara baik.

Berbagai metoda yang dapat menurunkan kadar logam berat yang larut dalam air antara lain: presipitasi, ion exchange, elekrodialisis, reverse osmosis, ultra filtrasi, serta adsorpsi.

Melalui penelitian ini yang mengkombinasi proses presipitasi dan adsorpsi dimaksudkan sebagai masukan konsep penanganan limbah B3 yang baik di Laboratorium Analisis Polinela untuk mengimplementasikannya sehingga tidak mengganggu ekosistem air tanah.

\section{Tujuan Penelitian}

Tujuan khusus penelitian ini adalah untuk mendapatkan hasil kombinasi yang tepat dalam perlakuan presipitasi dan perlakuan absorbsi untuk menghilangkan kandungan bahan pencemar B3 dari buangan limbah cair Laboratorium Analisis polinela.

\section{METODA PENELITIAN}

\section{Tempat dan Waktu Penelitian}

Penelitian ini dilakukan di laboratorium di laboratorium Analisis Politeknik Negeri Lampung. Waktu pelaksanaan penelitian ini direncanakan pada bulan Juli sampai dengan bulan Oktober 2019.

\section{Alat dan Bahan}

\section{Alat Penelitian}

1. AAS (Atomic Absorption Spectrophotometer)

2. Alat Flokulasi

3. $\mathrm{pH}$ meter

66 Volume 12, Nomor 1| Agustus 2020: 65-126 
4. Alat becker glass, Gelas ukur, Tabung reaksi dan lain sebagainya

\section{Bahan Penelitian}

1. $\mathrm{Ca}(\mathrm{OH})_{2}$ teknis

2. Akuades

3. Kapur

4. Larutan Buffer dan 7

5. Arang Aktif

\section{Tahapan Penelitian}

Tahapan pelaksanaan penelitian untuk mendapatkan dasar konsep kombinasi proses presipitasi metode hidroksida dengan adsorpsi secara skematis dapat dilihat pada Gambar 1.

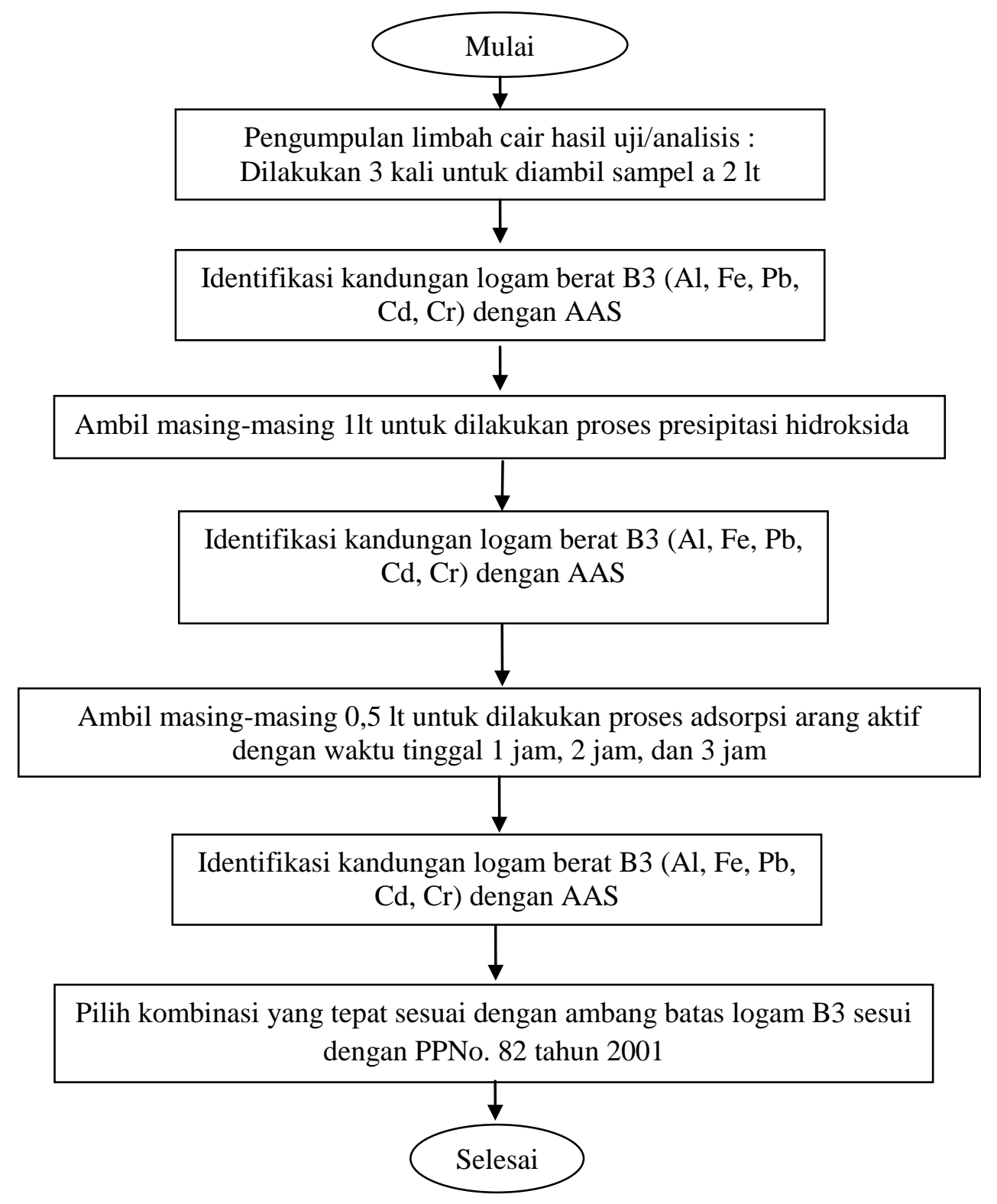

Gambar 1. Skema Tahapan Penelitian 


\section{Prosedur Presipitasi hidroksida}

1. Membuat larutan $\mathrm{Ca}(\mathrm{OH})_{2}$ 0,6 $\mathrm{M}$ dengan menggunakan labu takar

2. Mengambil Sampel limbah cair sebanyak $200 \mathrm{ml}$, dimasukkan dalam beaker glass $500 \mathrm{ml}$

3. Menambahkan larutan $\mathrm{Ca}(\mathrm{OH})_{2}$ 0,2 M sampai diperoleh $\mathrm{pH} 7$

4. Mengaduk dengan flokulator dengan kecepatan $100 \mathrm{rpm}$ selama 2 menit dan $50 \mathrm{rpm}$ selama 40 menit

5. Campuran didiamkan selama 24 jam sehingga terbentuk endapan

6. Mengambil larutan yang tidak mengendap, selanjutnya lakukan pengujian dengan AAS

\section{Prosedur Adsorpsi arang aktif}

1. Mengambil $100 \mathrm{ml}$ larutan hasil proses presipitasi

2. Lakukan proses adsorpsi dengan arang aktif perlakukan waktu tinggal 1 jam, 2 jam, dan 3 jam

3. Mengambil larutan hasil adsorpsi, selanjutnya lakukan pengujian dengan AAS

\section{Prosedur pembuatan arang untuk karbon aktif}

1. Tempurung kelapa dalam kondisi kering dibakar untuk dibuat arang

2. Arang dari tempurung kelapa dibuat butiran dengan cara dihancurkan dan diayak dengan mesh ukuran $2 \mathrm{~mm}$

3. Butiran arang direndam dengan larutan $\mathrm{Hcl} 0,01 \mathrm{~N}$ selama 24 jam

4. Selanjutnya bitiran arang dioven suhu 250 derajat Celcius selama 24 jam

\section{Data yang diamati}

Data yang diamati dalam penelitian ini adalah konsentrasi kandungan logam berat B3 (Al, $\mathrm{Fe}, \mathrm{Pb}$, dan $\mathrm{Cd}$ ) sebelum dan setelah proses yang akan diuji di Laboratorium Analisi Polinela

\section{HASIL DAN PEMBAHASAN}

\section{Identifikasi Pencemar B3 pada limbah cair Laboratorium Analisis Polinela}

Pada tahap identifikasi ini, pekerjaan dimulai dari pengambilan sampel yang dilakukan pada bulan Mei dengan pengambilan sampel 3 (tiga) kali: awal bulan, tengah bulan, dan akhir bulan. Hasil kandungan bahan pencemar B3 dapat dilihat pada tabel 1.

Dari Tabel 1. terlihat pada limbah hasil proses di Laboratorium Analisis Polinela didonimasi bahan pencemar B3 berupa logam besi (Fe) dan alumunium ( $\mathrm{Al}$ ): sedangkan logam cadmium $(\mathrm{Cd})$ hampir dapat dikatakan sangat kecil, chromium $(\mathrm{Cr})$ dan timbal $(\mathrm{Pb})$ tidak terdeteksi. Dari hasil ini tergambar bahwa reagen untuk bahan reaksi pada kegiatan bulan Mei banyak mengandung bahan pencemar Fe dan Al. 
Tabel 1. Hasil Analisis Identifikasi Bahan Pencemar B3 limbah Laboratorium Analisis

\begin{tabular}{cccccc}
\hline \multirow{2}{*}{ No } & \multirow{2}{*}{ Parameter } & \multicolumn{4}{c}{ Hasil Analisis (ppm) } \\
\cline { 3 - 6 } & & Sampel 1 & Sampel 2 & Sampel 3 & Rata-Rata \\
\hline 1 & $\mathrm{Al}$ & 1,1 & 1,73 & 1,93 & 1,59 \\
\hline 2 & $\mathrm{Fe}$ & 5,93 & 10,94 & 10,82 & 9,23 \\
\hline 3 & $\mathrm{~Pb}$ & $\mathrm{tt}$ & $\mathrm{tt}$ & $\mathrm{tt}$ & $\mathrm{tt}$ \\
\hline 4 & $\mathrm{Cd}$ & 0,007 & 0,031 & 0,028 & 0,022 \\
\hline 5 & $\mathrm{Cr}$ & $\mathrm{tt}$ & $\mathrm{tt}$ & $\mathrm{tt}$ & $\mathrm{tt}$ \\
\hline Keterangan & $\begin{array}{l}\text { Sampel 1, sampel pengambilan awal bulan } \\
\text { Sampel 2, sampel pengambilan tengah bulan }\end{array}$ & \\
& $\begin{array}{l}\text { Sampel 3, sampel pengambilan akhir bulan } \\
\end{array}$ & & &
\end{tabular}

\section{Hasil Proses Presipitasi}

Selanjutnya limbah dengan kandungan bahan pencemar B3 telah teridentifikasi dilakukan proses presipitasi dengan Kalsium Hidroksida $\left(\mathrm{Ca}(\mathrm{OH})_{2}\right.$. Hasil prseipitasi dapat menurunkan pencemar Al sebesar rata-rata 29,31\% seperti terlihat pada Tabel 2.

Tabel 2. Hasil Proses Presipitasi dalam Menurunkan kadar bahan pencemar Al

\begin{tabular}{rrrrr}
\hline \multirow{2}{*}{ No } & \multirow{2}{*}{ Sampel } & \multicolumn{3}{c}{ Hasil Proses Presipitasi (ppm) } \\
\cline { 3 - 5 } & & sebelum & sesudah & $\%$ penurunan \\
\hline 1 & Sampel 1 & 1,1 & 1,01 & $8,18 \%$ \\
\hline 2 & Sampel 2 & 1,72 & 1,12 & $34,88 \%$ \\
\hline 3 & Sampel 3 & 1,93 & 1,06 & $45,08 \%$ \\
\hline \multicolumn{5}{c}{ Rata-Rata } \\
\hline
\end{tabular}

Sedangkan untuk bahan pencemar Fe hasil proses presipitasi dapat diturunkan sebesar 98,34\% seperti terlihat pada Tabel 3 .

Tabel 3. Hasil Proses Presipitasi dalam Menurunkan kadar bahan pencemar Fe

\begin{tabular}{rrrrr}
\hline \multirow{2}{*}{ No } & \multirow{2}{*}{ Sampel } & \multicolumn{3}{c}{ Hasil Proses Presipitasi (ppm) } \\
\cline { 3 - 5 } & & sebelum & sesudah & \% penurunan \\
\hline 1 & Sampel 1 & 5,9 & 0,1 & $98,31 \%$ \\
\hline 2 & Sampel 2 & 10,94 & 0,189 & $98,27 \%$ \\
\hline 3 & Sampel 3 & 10,82 & 0,168 & $98,45 \%$ \\
\hline \multicolumn{5}{c}{ Rata-rata } \\
\hline
\end{tabular}

Dari kedua tabel tersebut dapat digambarkan bahwa kandungan pencemar Fe yang jauh lebih besar dari kandungan bahan pencemar $\mathrm{Al}$, dengan proses presipitasi dapat lebih dihilangkan/diturunkan secara lebih signifikan. 


\section{Hasil Proses Adsorbsi}

Setelah dilakukan proses presipitasi, dilanjutkan dengan proses adsorpsi dengan menggunakan adsorben arang aktif, dengan waktu kontak 1 jam, 2 jam dan 3 jam dengan hasil penurunan bahan pencemar Al sebesar rata-rata 18,19\% dengan besaran yang linier dengan waktu kontak, yakni makin lama waktu kontak makin besar pula prosentasi penurunan bahan pencemar $\mathrm{Al}$ seperti terlihat pada Tabel 4.

Tabel 4. Hasil Proses Adsorpsi dalam Menurunkan kadar bahan pencemar Al

\begin{tabular}{|c|c|c|c|c|c|}
\hline \multirow{2}{*}{ No } & \multirow{2}{*}{ Sampel } & \multicolumn{4}{|c|}{ Hasil Proses Adsorbsi (ppm) } \\
\hline & & sebelum & waktu kontak & sesudah & \% penurunan \\
\hline 1 & Sampel 1 & 1,01 & $1 \mathrm{jam}$ & 0,857 & $15,15 \%$ \\
\hline 2 & Sampel 2 & 1,12 & $2 \mathrm{jam}$ & 0,916 & $18,21 \%$ \\
\hline 3 & Sampel 3 & 1,06 & 3jam & 0,813 & $23,30 \%$ \\
\hline \multicolumn{5}{|c|}{ Rata-rata } & $18,89 \%$ \\
\hline
\end{tabular}

Sedangan untuk bahan pencemar $\mathrm{Fe}$ dengan perlakuan adsorbs yang sama dapat menurunkan bahan pencemar Fe rata-rata sebesar 29,93\% seperti terlihat pada Tabel 5. berikut

Tabel 5. Hasil Proses Adsorpsi dalam Menurunkan kadar bahan pencemar Fe

\begin{tabular}{ccrcrc}
\hline \multirow{2}{*}{ No } & \multirow{2}{*}{ Sampel } & \multicolumn{4}{c}{ Hasil Proses Adsorbsi (ppm) } \\
\cline { 3 - 6 } & & sebelum & waktu kontak & sesudah & \% penurunan \\
\hline 1 & Sampel 1 & 0,1 & 1 jam & 0,08 & $20,00 \%$ \\
\hline 2 & Sampel 2 & 0,189 & 2 jam & 0,11 & $41,80 \%$ \\
\hline 3 & Sampel 3 & 0,168 & 3 jam & 0,121 & $27,98 \%$ \\
\hline \multicolumn{5}{c}{ Rata-rata } \\
\hline
\end{tabular}

\section{Luaran Bahan Pencemar Hasil Kombinasi Proses}

Dari kombinasi proses presipitasi dan proses adsorpsi buangan limbah Laboratorium Analisis Polinela dapat didiskripsikan bahwa dari bahan pencemar B3 behasil diturunkan di bawah ambang batas bahan pencemar $\mathrm{Al}$ dan Fe sesuai kentuan PP No 82 tahun 2001 tentang baku mutu air. Dengan demikian hasil luaran kombinasi prsoses tersebut dapat dikatakan aman untuk dibuang ke perairan.

\section{KESIMPULAN DAN SARAN}

\section{Kesimpulan}

1. Laboratorium Analisis Polinela pada bulan Mei 2019 dalam kegiatannya banyak mengandung bahan B3 dengan pencemar $\mathrm{Fe}$ dan $\mathrm{Al}$

2. Proses presipitasi $\mathrm{Ca}(\mathrm{OH})_{2}$ dapat menurunkan kandungan pencemar logam $8 \%-98,45 \%$ 
3. Proses adsorbsi yang dilakukan setelah proses presipitasi dapat menurunkan kandungan pencemar logam $15,15 \%-41,80 \%$

4. Kombinasi perlakuan presipitasi $\mathrm{Ca}(\mathrm{OH})_{2}, 0,8 \mathrm{M}$ dan adsorbsi arang aktif dengan waktu kontak 3 jam memberikan efektifitas paling baik, sehingga apabila dibuang ke bak penampung limbah cair di lab analisis sudah mempunyai karakter limbah bahan pencemar logam kurang dari 1 ppm

\section{Saran}

Dari kesimpulan tersebut sebaiknya dilakukan untuk metoda preipitasi dan adsorpsi yang lain sehingga dapat diperbandingkan efektivitasnya dalam menurunkan limbah dengan pencemar B3

\section{DAFTAR PUSTAKA}

Ayres, David M, Allen P \& Gietka, Paul M 1994 Removing Heavy Metals from Wastewater. University of Maryland. Enggineering Reserch Report

Chanel Tri Handoko, Tri Budi Yanti, Halimatus Syadiyah, Siti Marwati. 2013. Penggunaan Metode Presipitasi Untuk Menurunkan Kadar Cu Dalam Limbah Cair Industri Perak di Kotagede. Jurnal Penelitian Saintek Vol 18 Nomor 2 51-58

Erdem, E, Karapinar \& Donat R. 2004. The Removal of Heavy Metal cations by Natural Zeolite. Journal of Colloid and Interface Science, 280:309-314

Fandeli Chafid. 1995. Analisis Mengenai Dampak Lingkungan Prinsip dasar dan Pemapanannya dalam Pembangunan. Penerbit Liberty. Yogyakarta

Mahmood B.M, Abid, Balasim A \& Al Shuwaiki, Najah M. 2011. Removal of heavy metals using chemicals precipitation. Eng. \& Tech Journal. 29 (3) 595-612

Michael D. La Grega dkk. 2001. Hazardous Waste Management. Mc. Graw Hill. New York.

Palar H.1994. Pencemaran dan Toksikologi logam Berat. Rineka Cipta. Jakarta

Raharjo Nugro. 2014. Teknik Pengolahan Limbah Cair Dengan Proses Kimia. Edisi Revisi. Universitas Atma Jaya. Yogyakarta 